\title{
QTL associated with resistance to defoliation (Cylindrocladium pteridis) in Eucalyptus spp.
}

\author{
Talyta G Zarpelon', Lúcio MS Guimarães ${ }^{1 *}$, Marcelo M Coutinho², Braz Cápua Neto', Danielle A Faria ${ }^{3}$, \\ Dario Grattapaglia ${ }^{3}$, Acelino C Alfenas ${ }^{1}$ \\ From IUFRO Tree Biotechnology Conference 2011: From Genomes to Integration and Delivery \\ Arraial d'Ajuda, Bahia, Brazil. 26 June - 2 July 2011
}

Leaf blight and defoliation caused by Cylindrocladium pteridis is one of the main leaf diseases found in Brazilian eucalypt plantations in warm and high rainfall regions. The inter and intraspecific variability in the intensity of defoliation indicate that your control can be achieved by planting resistant genotypes. In order to guide breeding programs and to predict the stability of resistance is essential to understand the genetic control of resistance in eucalypts to defoliation. Thus, the objectives of this paper were to map QTLs (Quantitative Trait Loci) associated with resistance to defoliation in a Eucalyptus urophylla $\times$ E. camaldulensis (EU11 x EC06) family and validate microsatellite markers linked to QTLs in four unrelated pedigrees involving different Eucalyptus species. Defoliation was evaluated on the branches of the lower third of the plants inoculated under controlled conditions. We identified five QTLs for resistance to defoliation (Rd), three on the map of the parental EU11, Rd-1 and Rd-2 located on linkage group (LG) 1 and Rd-4 located on LG6; and two QTLs located on the map of the parental EC06, present in LG2 (Rd-3) and LG8 (Rd-5). Markers linked to QTLRd2 were validated in two unrelated families by simple linear regression analysis. This is the first genomic map of QTLs associated with resistance to defoliation caused by C. pteridis in Eucalyptus.

\section{Author details}

${ }^{1}$ Universidade Federal de Viçosa, Brazil. ${ }^{2}$ Clonar Resistência a Doenças

Florestais, Brazil. ${ }^{3}$ Embrapa Cenargen, Brazil.

Published: 13 September 2011

* Correspondence: luciomsguimaraes@yahoo.com.br

'Universidade Federal de Viçosa, Brazil

Full list of author information is available at the end of the article
doi:10.1186/1753-6561-5-S7-P27

Cite this article as: Zarpelon et al:: QTL associated with resistance to defoliation (Cylindrocladium pteridis) in Eucalyptus spp.. BMC Proceedings 2011 5(Suppl 7):P27.
Submit your next manuscript to BioMed Central and take full advantage of:

- Convenient online submission

- Thorough peer review

- No space constraints or color figure charges

- Immediate publication on acceptance

- Inclusion in PubMed, CAS, Scopus and Google Scholar

- Research which is freely available for redistribution
() Biomed Central 